\title{
Research on Application of Performance Evaluation Index System of Universities
}

\author{
Zhao Libing \\ Chengde Medical University \\ Chengde, Hebei, 067000 China
}

\begin{abstract}
Universities and colleges are the base cultivating high-quality talents, and national finance makes significant investment. If the investment of funds and resources of stakeholders of universities is really worthy and is good for the development of universities makes the performance evaluation of universities attract the attention of stakeholders in universities. The paper uses prism performance model to set a comprehensive index system of performance evaluation of universities in China. The comparative research on performance of universities achieves the difference between universities in different regions. And the paper proposes countermeasures and suggestions according to the research results.
\end{abstract}

Keywords-universities, performance evaluation, prism performance model, index system

\section{INTRODUCTION}

Ministry of education proposed that implementing the strategy of rejuvenating the country through science and education not only must transform the concept of using education investment as consumption investment and develop education as infrastructure construction, but also needs to regard education investment as a fundamental investment, and increase the investment of education. According to the above requirements, using performance evaluation and performance management, evaluating utilization efficiency of school resources, promoting reasonable optimization allocation on limited education resources and researching the status of performance evaluation of universities, and exploring healthy performance evaluation index system not only can promote self-teaching and workflow of universities, and promote the strength of self-development of universities, but also provides basis for government to make objective and comprehensive evaluation on performance of universities.

\section{APPLICATION OF PERFORMANCE PRISM MODEL}

\section{A. Performance Prism model}

Performance Prism model was proposed by Andy KeeIy, Chris Adams and Mike Kennerley in 2000. The theoretical basis of Performance Prism is stakeholder theory. Performance Prism model has the background of natural public administration, and has adaptability and feasibility for application of performance evaluation of universities. The difference from common performance evaluation framework is that it concerns all important stakeholders. It not only achieves contribution from stakeholders, but also concerns the satisfaction of stakeholders, which has double meaning, results orientation and behavior orientation. It not only indicates the logic relationship between performance results and driving factors, but also reflects the influence on results. The evaluation summarizes the characteristics of performance evaluation in universities comprehensively and scientifically.

\section{B. Design scheme of prism performance model establishing performance evaluation index system of universities}

Because the paper length and research data is limited, combined with the idea of prism performance model, for the selection of indexes, the paper uses strengthening overall operation condition of universities as the objective to design indexes of prism performance model. Based on the existing Financial Rules of Public Service Unit and Financial System of Universities, the paper refers to China University Performance Evaluation Report and researches the evaluation index system.

(1) Performance measurement indicator of teachers, administrators and students

The performance evaluation indicators of teachers, administrators and students are necessary in performance evaluation of universities. The ability and quality, satisfaction degree and enthusiasm of teachers, administrators and students influence the realization of development objective in universities. The performance evaluation system of universities selects 16 indicators, and makes comprehensive evaluation on five indicatory types, as shown in Table 1. 
Table 1 Performance measurement indicators based on teachers, administrators and students

\begin{tabular}{|c|c|c|}
\hline Division basis & $\begin{array}{l}\text { Index } \\
\text { number }\end{array}$ & Index name \\
\hline \multirow{3}{*}{$\begin{array}{l}\text { Stakeholder } \\
\text { satisfaction }\end{array}$} & A01 & Total amount of capital investment of the year \\
\hline & A02 & Students' average budget allocated by the government \\
\hline & $\mathrm{A} 03$ & Total amount of investment of scientific research funds \\
\hline \multirow{3}{*}{ Strategy } & A04 & $\begin{array}{cllll}\text { Expenditure } & \text { of } & \text { developing } & \text { teaching } & \text { and } \\
\text { auxiliary activities } & & & & \end{array}$ \\
\hline & A05 & Expenditure of scientific research institutions \\
\hline & A06 & Teacher-student ratio of schools \\
\hline \multirow{4}{*}{ Flow } & A07 & $\begin{array}{l}\text { Number of training teachers in full-time teachers in the } \\
\text { school year }\end{array}$ \\
\hline & A08 & $\begin{array}{l}\text { Number of scientific research teachers in full-time } \\
\text { teachers in the school year }\end{array}$ \\
\hline & A09 & Number of students at school \\
\hline & A10 & $\begin{array}{l}\text { Expenditure of purchasing instruments for scientific } \\
\text { research }\end{array}$ \\
\hline \multirow{4}{*}{ Ability } & A11 & Number of published papers \\
\hline & A12 & Application achievement \\
\hline & A13 & Number of first prize \\
\hline & A14 & Number of second prize \\
\hline \multirow{2}{*}{$\begin{array}{l}\text { Stakeholder } \\
\text { contribution }\end{array}$} & A 15 & Proportion of associate professors \\
\hline & A16 & Employment rate \\
\hline
\end{tabular}

Performance evaluation index based on government level is very important for performance evaluation of universities.

(2)Performance measurement index based on The performance evaluation system of government for government level universities uses 10 indicators, and makes comprehensive evaluation on five index types, as shown in Table 2 .

Table 2 Performance measurement index based on government level

\begin{tabular}{ccc}
\hline Division basis & $\begin{array}{c}\text { Index } \\
\text { number }\end{array}$ & Index name \\
\hline \multirow{2}{*}{$\begin{array}{c}\text { Stakeholder } \\
\text { satisfaction }\end{array}$} & B01 & Employment rate \\
& B02 & Scientific research awards \\
& B03 & Social evaluation \\
& B04 & Education awards \\
\hline Strategy & B05 & Number of important subjects \\
\hline Flow & B06 & Employment rate \\
Ability & B07 & Number of important subjects \\
\hline Stakeholder & B08 & Total amount of national \\
investment
\end{tabular}

(3) Performance measurement index based on alumni and donator level

Performance measurement index based on alumni and donator level is important for performance evaluation of universities. Alumni and donators indirectly influence the realization of development objective of universities. The performance evaluation system of alumni and donators on universities selects 9 indicators and makes comprehensive evaluation on five index types, as shown in Table 3. 
Table 3 Performance measurement index based on alumni and donator level

\begin{tabular}{ccl}
\hline Division basis & $\begin{array}{c}\text { Index } \\
\text { number }\end{array}$ & Index name \\
\hline $\begin{array}{c}\text { Stakeholder } \\
\text { satisfaction }\end{array}$ & $\mathrm{C} 01$ & $\begin{array}{c}\text { Times of effective donation } \\
\text { Relationship quality of alumni, donators and } \\
\text { schools }\end{array}$ \\
\hline Strategy & $\mathrm{C} 03$ & $\begin{array}{c}\text { Development power of donation channels } \\
\text { Stability of donation }\end{array}$ \\
\hline Flow & $\mathrm{C} 04$ & $\begin{array}{c}\text { Maintenance management level on relationship } \\
\text { between donators and alumni }\end{array}$ \\
\hline Ability & $\mathrm{C} 05$ & Proportion of donation income to total income \\
$\begin{array}{c}\text { Stakeholder } \\
\text { contribution }\end{array}$ & $\mathrm{C} 06$ & Economic capability of donators \\
\hline
\end{tabular}

(4) Performance measurement index based on citizen, community and media level

A university is the citizen of the community, which has an influence on the economic development, employment and environment of the region. And the activities of universities can't be separated from the support of the local citizen, community and media including labor market and government policies. Harmonious community relationship helps the university to establish good public image and reputation, which attracts the attention of donators and schools, and expands the influencing power to realize the competition of sustainable development of universities. The performance evaluation of citizen, community and media on universities selects 9 indicators and makes comprehensive evaluation on five index types.

\section{Calculation of index weight}

When the performance of a school is evaluated, the evaluation index weight of the index system not only directly influences the reliability of evaluation results, but also guides the direction of managers in universities. The greater the weight of the index is, the greater the possibility to attract the attentions of managers in universities is. When performance evaluation index weight is set, the quality features of evaluation index, accuracy and consistency, are important factors of weight allocation.

The paper issues 10 questionnaires to the universities in the west, middle and east of China for surveying performance evaluation index weight of universities. And 56 questionnaires are recycled. The paper uses scatter degree grading method to calculate index weight, and divides the index into five levels, the most important, very important, important, more important and generally important. The value of the most important level is 5 scores, the value of very important level is 4 scores, and the value of generally important is 1 score. The index which is not selected is 0 . The indexes which are selected repeatedly are calculated according to the mean of grading score, which achieves the score of each index.

The calculation formula of index weight is $w_{i}=X_{i} / \sum X_{i} . \mathrm{Xi}$ is the total score of evaluation indexes, and $\sum \mathrm{Xi}$ is the total score of all evaluation indicators, which can achieve the calculation result of index weight.

\section{EMPIRICAL RESEARCH}

\section{A. Data source}

The data of evaluation index is from Data Compilation of Education Ministry on Universities in 2012. Some indexes are not completely consistent for statistic caliber, calculation method and special range, and the index data is achieved after conversion. In order to ensure the integrity and consistency of data, the acquisition and calculation of data is completed by the writer.

\section{B. Calculation and results of index data}

In order to make comprehensive and objective performance evaluation of universities, and avoid the problem of overlapping of different indexes, the paper makes systematic and organic evaluation on indexes, stakeholder satisfaction, strategy, flow, ability and stakeholder contribution.

(1)Index conversion

The performance evaluation of universities based on teachers, administrators and students dimension uses different comprehensive index forms such as absolute number and relative number, and the dimensions of indexes are different, which needs to transform the evaluation indexes which can ' $t$ be added directly into the index values which can be directly added or multiplied. The paper uses efficiency coefficient method to convert indexes.

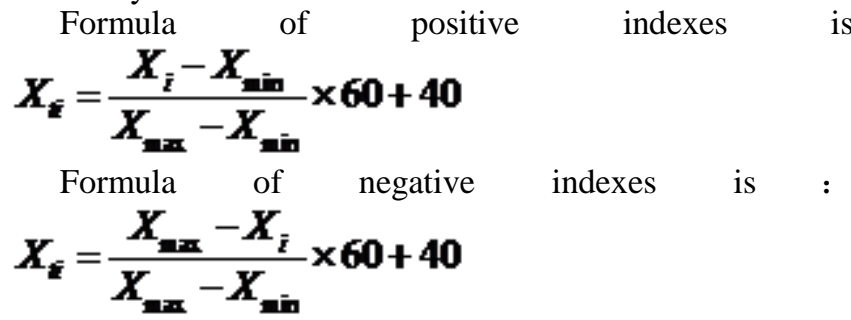

$X_{t i}$ is the efficient coefficient value, $X_{i}$ is the real value of index, $X \min$ is the minimum of index, and Xmax is the maximum of the index. 


\section{(2)Performance} subordinate universities of ministry of education

After making dimensionless treatment on evaluation indicators, the real index value of each index is converted into the quantization value with unified significance and integration. It is not influenced by evaluation indicators, and has linear additivity. The paper uses the following comprehensive evaluation model.

$$
y=\sum_{j=1}^{a} w_{j} x_{j}
$$

$w_{i}$ is the evaluated index weight and $x_{i}$ s evaluation index.

According to the formula, we can calculate the results of performance evaluation of universities. And the stakeholder satisfaction, strategy, flow, ability and stakeholder contribution of 75 universities receives performance evaluation. And the comprehensive performance evaluation of 75 universities is ordered.

\section{Evaluation results analysis}

(1)Analysis of performance evaluation results of universities

From the analysis results of the model, we can get the performance comparison of subordinate universities of Ministry of Education, and the total score and rank of performance in different universities helps the universities to know the features, working modes and methods. For example, there is great difference for total score in subordinate universities of Ministry of Education. Tsinghua University which is the first has great difference for grade from China Pharmaceutical University which is the last, which not only is influenced by environmental change, but also relates to non-scientific and irrational management and resource allocation of universities.

(2) Comparative analysis on performance evaluation results of universities in the east, middle and west of China

The universities in the east of China rank the first, and the universities in the middle and west of China are secondary. Combined with the original data analysis, the reputation and scientific research level of universities in the east of China is high, the investment of scientific research and teaching is great, and the performance indexes are high, but the performance index value of universities in the west of China is low. We can see that the investment of universities in the east is the largest, that in the west is secondary and that in the west is the lowest. In addition, the universities in the east have higher performance management level and resource utilization efficiency is the highest, that in the middle is secondary, and that in the west is the lowest.

(3) Comparative analysis on performance evaluation results of different types of universities

The position of the first for each type of university in 75 universities is as follows. Tsinghua University which is the first in comprehensive university ranks the first. Tongji University with the first in science and engineering college ranks the eighth. East China Normal University with the first in normal college ranks the eighth. China Agricultural University which is the first in agriculture and forestry colleges ranks the twenty-eighth. Zhongnan
University of Economics and law which is the first in politics and law colleges rank the forty-eleventh. Beijing Foreign Language University which is the first in language colleges ranks the forty-fifth. Shanghai Finance University with the first in financial colleges ranks the forty-seventeenth. Central Academy of Drama with the first in art colleges ranks the sixty-second. Beijing University of Chinese Medicine with the first in medical colleges ranks the seventy-second. The performance of comprehensive colleges is the best, and that of medical colleges is the worst. Combined with the original index data, the results comparison reflects that the performance of comprehensive, scientific and engineering and normal colleges is better, the management level and resource utilization efficiency of schools is higher, and the performance of medical and art colleges is worse, and the performance management level of schools is weak.

From the comparative analysis on performance evaluation results of 175 subordinate universities of Ministry of Education, we can see the management level and resource allocation and utilization of each college. But some problems can't be measured by simple number, the reason for which is that making profit is not the objective of the universities in our country, and the university is a complicated social department. Therefore, the evaluation results of performance in universities are not only number, but also should provide reference for managers of universities to formulate development strategy and measures.

\section{CONCLUSION}

75 subordinated universities of Ministry of Education are taken as an example to make comprehensive evaluation and analysis on performance indicators. Subordinated university of Ministry of Education is an important part of university system, and has great influence on university, so the performance of the universities directly influences the establishment and development of universities. Selecting subordinated universities of Ministry of Education as evaluation samples is typical and universal. In order to ensure the feasibility and representation of evaluation index system and evaluation model, the writer investigates more than 30 universities in China, and achieves the direct data. And the writer uses weight design method and dimensionless method to research performance evaluation system, and solves the subjectivity and partial of evaluation process, which not only makes the performance evaluation results of universities more scientific, but also provides important basis for universities to make rational performance management system.

\section{REFERENCE:}

[1] Mary A. Malina, Frank H. Selto . Choice and Change of Measures in Performance Measurement Models [J]. Management Accounting Research. 2004, 12(15) .441-469

[2] Abdel-Maksoud, David Dugdale, Robert Luther. Non. financial performance measurement

[3] in manufacturing companies[J] . The British Accounting Review. 2005, 9(37). 261-297 
[4] Carter N. Greer P.1993,Evaluating agencies next step s and performance indicators. Public administration, 71:407-416.

[5] Guthrie J.E.and Parker L.D,1999,A Quarter of a Century of Performance Auditing in the Australian Federal Public Sector:A Malleable Masque(3):302-332.

[6] Cave,Martin,Hanny,Stephen and Kogan,Mauric,"The Use of Performance Indicators in Higher Education: A Critical Analysis of Developing Practice",Jessica Kingsleg Publishers Ltd. , 1988.P17,P20,P19-20,P106-107,P118-P39.
[7] Jaap Schenrens, CeesGlas, Sally H . Thoms : Educational Evaluation, Assessment, AtldMonitoring, A systemicApproach, Swcb\&Zeitlinger Publishers. 2003, P304

[8] Quinn E. R, Faerman R. S, Thompson P. M, McGrath $\mathrm{R}$. $\mathrm{M}$. . Becominga Master Manager : ACompany Framework. NewYork John W. 1ey\&Son, 1985. 